\title{
Efforts to Prevent Tuberculosis Transmission Based on the Health Belief Model Theory in West Lombok
}

\author{
Agus Supinganto ${ }^{1 *}$, Ina Kusrini², Asih Setyani' ${ }^{3}$, Lili Amaliah4, \\ Selasih Putri Isnawati Hadi ${ }^{5}$, Irwan Budiana ${ }^{6}$

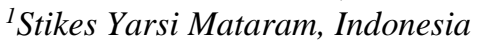 \\ ${ }^{2,3}$ Balai Litbang Kesehatan Magelang, Indonesia \\ ${ }^{4}$ Stikes Mahardika Cirebon, Indonesia \\ ${ }^{5}$ STIKES Guna Bangsa Yogyakarta, Indonesia \\ ${ }^{6}$ Poltekes Kemenkes Kupang, Indonesia \\ *agusping@gmail.com
}

\begin{abstract}
The community's high incidence of tuberculosis is closely related to behaviour, and family involvement. Transmission preventance becomes an important factor in controlling transmission of tuberculosis. The purpose of this study is to identify efforts to prevent tuberculosis transmission in western Lombok. Method. concise exploratory design using cross-sectional sampling of the sample using a purposeful sampling process with 58 respondents. Result. $72 \%$ of respondents took measures to prevent tuberculosis based on the health belief model, namely; perceived susceptibility $72 \%$; perceived seriousness $78 \%$; perceived benefits $81 \%$; perceived barriers $67 \%$; and cues to action $65 \%$. Duscussion. The need to improve family members' awareness about tuberculosis prevention and to practice safe and healthy living activities at all times.
\end{abstract}

Keywords: Prevention, Transmission, TB, HBM Theory 


\section{STRADA Jurnal Ilmiah Kesehatan}

DOI: $10.30994 /$ sjik.v9i2.463

ISSN: 2252-3847 (print); 2614-350X (online)

Vol.9 No.2 November 2020 Page.1274-1284

\section{BACKGROUND}

Tuberculosis (TB) is an infectious disease of the lungs caused by infection with mycobacterium tuberculosis. Tuberculosis is one of the biggest infectious diseases that cause death. Globally, the prevalence of TB in the world in 2017 was 7 million, and in 2018 there were 10 million new cases due to TB (WHO, 2019). New cases that occurred in 2018 reached $66 \%$ of cases with eight contributing countries, namely India, China, Indonesia, the Philippines, Pakistan, Nigeria, Bangladesh and South Africa (WHO, 2018). Riskesdas data also shows the prevalence of TB in West Nusa Tenggara Province is still $0.32 \%$ with the proportion of patients who consume routine drugs in NTB Province of 54.9\% (RISKESDAS, 2018), while data from Gunungsari Health Center, West Lombok, there are 58 tuberculosis patients. in 2019. The number of tuberculosis sufferers is $43 \%$ male, while $57 \%$ female. And in terms of age characteristics of the patient; There are 45 adults (15-49 years old) and 13 parents (50 years and over) (Puskesmas, 2019).

Patients with BTA (Acid Resistant Basil) TB positive are the main source of transmission through coughing or sneezing. Patients spread germs into the air in the form of droplet nuclei as well as environmental factors related to the concentration of germs in the air such as ventilation, ultraviolet light and air filtering (Kementerian Kesehatan RI, 2014). Close families with TB patients are the people most at risk for contracting TBcausing bacteria. Previous studies have shown that the large incidence of TB in families with known close contact with TB patients is that apart from being the individual most at risk for $\mathrm{TB}$, the family also has an important role to play. cure TB sufferers. The effectiveness of the role of the family in TB control is in the supervision of taking medication, where this program is considered effective in curing TB sufferers (Toth et al., 2004; Newell et al., 2006; Yekrang Sis et al., 2014). The report from the global TB report states that prevention of transmission by involving families and communities is very important so that the specific targets set out in the final TB Strategy include a 90\% reduction in TB deaths and an $80 \%$ reduction in TB incidence (new cases per year) by 2030 (WHO, 2019). Efforts to prevent the transmission of tuberculosis are related to behavior. Rosesnstock 1982 Health Belief Model (HBM) theory is used to identify prevention efforts carried out by families with TB sufferers. Given that families are the most at risk of contracting TB. In this theory it states that prevention efforts will be carried out when the perception is individuals feel threatened by symptoms of the disease they suffer. Then the individual will seek help when he feels threatened by his health.

Factors that affect individuals in preventing disease include perceived susceptibility (if the individual feels the disease is a threat to take treatment), perceived seriousness (individual action on how severe the disease is for treatment), perceived benefits (benefits that individuals feel when taking treatment), perceived barriers (other effects felt by individuals after treatment), as well as elements of cues to action (cues or motivation to take preventive and therapeutic measures) (Sinaga and Josetta, 2009). This study aims to determine efforts to prevent tuberculosis transmission through HBM theory approach by families of TB sufferers.

\section{METHODS}

This research is a descriptive exploratory study using a cross-sectional study design, namely research that describes events by way of data collection carried out in one time with a questionnaire and variable measurement. The population of this study were all household contacts of tuberculosis patients who were in Gunungsari District, West Lombok Regency during October to December 2019, as many as 58 people. The sample 


\section{STRADA Jurnal Ilmiah Kesehatan}

DOI: $10.30994 /$ sjik.v9i2.463

ISSN: 2252-3847 (print); 2614-350X (online)

Vol.9 No.2 November 2020 Page.1274-1284

was taken using a non-probability sampling technique using a purposive sampling method based on the inclusion and exclusion criteria set by the researcher. The questionnaire containing questions about the prevention of tuberculosis transmission used HBM theory, each 10 questions with the alternative answers choosing the most correct answer, the correct statement was given The value of 1 and wrong is given a value of 0 . As for the attitude questionnaire using the Likert scale, namely strongly agree, agree, disagree and strongly disagree with the question items including categories of perceived susceptibility, perceived seriousness, perceived benefits, perceived barriers, and cues to action. Furthermore, they were categorized into good, adequate and insufficient. Data analysis was carried out descriptively using licensed SPSS software.

\section{RESULTS AND DISCUSSION}

Respondent Demographic Data

Demographic data of respondents whose frequency distribution can be seen in Table 1 below:

Table 1. Frequency Distribution of West Lombok Tuberculosis Demographic Data Year $2019(\mathbf{n}=58)$

\begin{tabular}{|c|c|c|c|}
\hline No & Demographic Data & Frequency & Percentage \\
\hline \multirow[t]{5}{*}{1} & Age: & & \\
\hline & Young Adult & 30 & 51,72 \\
\hline & Middle Adult & 20 & 34,48 \\
\hline & Advanced Adult & 8 & 21,62 \\
\hline & Total & 58 & 100 \\
\hline \multirow[t]{4}{*}{2} & Gender: & & \\
\hline & Male & 37 & 42,50 \\
\hline & Women & 21 & 57,50 \\
\hline & Total & 58 & 100 \\
\hline \multirow[t]{5}{*}{3} & Last Education & & \\
\hline & Low & 31 & 53,45 \\
\hline & Intermediate & 25 & 43,10 \\
\hline & High & 2 & 3,45 \\
\hline & Total & 58 & 100 \\
\hline \multirow[t]{6}{*}{4} & Profession & & \\
\hline & Servants Civil & 0 & 0 \\
\hline & Private & 0 & 0 \\
\hline & Farmer & 20 & 34,48 \\
\hline & Traders & 38 & 65.52 \\
\hline & Total & 58 & 100 \\
\hline
\end{tabular}

Source: Primary Data

Based on table 1, the highest age is in the young adult age group (18-40 years) (51.72\%), the highest gender is male $(42.50 \%)$, the highest last education is low education $(53.45 \%)$, most occupations are traders $(65.52 \%)$. 


\section{STRADA Jurnal Ilmiah Kesehatan}

DOI: $10.30994 /$ sjik.v9i2.463

ISSN: 2252-3847 (print); 2614-350X (online)

Vol.9 No.2 November 2020 Page.1274-1284

Tuberculosis Recurrence Prevention based on the Health Belief Model Theory in West Lombok

Recurrence prevention measures taken by respondents against tuberculosis according to the mean value of each HBM variable were categorized as prevention and not prevention. The re

sults of the measurement using a questionnaire with a total of 58 respondents based on table 2 were obtained as many as 42 respondents with a percentage of $72 \%$ both in preventing recurrence of tuberculosis and 12 respondents with a percentage of $21 \%$ who were less in making efforts to prevent recurrence of tuberculosis.

Table 2. Frequency Distribution of Tuberculosis Recurrence Prevention Efforts in West Lombok in $2019(n=58)$

\begin{tabular}{llll}
\hline No & Prevention & Frequency & Percentage \\
\hline 1. & Good & 42 & 72 \\
\hline 2. & Enough & 4 & 7 \\
\hline 3. & Less & 12 & 21 \\
\hline Total & & 58 & 100 \\
\hline
\end{tabular}

Source: Primary Data

Healthy living behavior to prevent the transmission of tuberculosis is influenced by individual perceptions because the increased knowledge after obtaining information about the risk of tuberculosis, the participation of health workers in providing information through extension programs also affects it. The more vulnerable a person is to a disease, the better to behave healthily in prevention. Perceptions of vulnerability that are felt by individuals will affect behavior to prevent pulmonary TB transmission. Research conducted on patients in Perak Surabaya found $68.6 \%$ of the perception of susceptibility to good proportional to preventive behavior (Firda Safira Ali, Setiawan, 2020). Knowledge is obtained from sharing patients with health workers either through posters in the Puskesmas, the internet or from counseling, an increase of $33.3 \%$ after counseling for pulmonary TB patients at the Simomulyo Health Center Surabaya (Patricia Nevada Bilqis, Darjati, 2020).

\section{(Perceived Susceptibility}

Perceived susceptibility of respondents to tuberculosis based on table 3 below, there are 42 respondents $(72 \%)$ who are good at prevention seen from their perceived susceptibility.

Table 3. Frequency Distribution of Efforts to Prevent Tuberculosis Recurrence in terms of Perceived Susceptibility in West Lombok in $2019(n=58)$

\begin{tabular}{llll}
\hline No & rceived Susceptibility) & & Percentage \\
\hline 1. & Good & 42 & 72 \\
\hline 2. & Enough & 4 & 7 \\
\hline 3. & Less & 12 & 21 \\
\hline Total & & 58 & 100 \\
\hline
\end{tabular}

Source: Primary Data

(Perceived Seriousness

Perceived seriousness of Tuberculosis based on table 4 shows as many as 48 respondents $(78 \%)$ both in taking prevention seen from the severity felt. 
STRADA Jurnal Ilmiah Kesehatan

DOI: $10.30994 /$ sjik.v9i2.463

ISSN: 2252-3847 (print); 2614-350X (online)

Vol.9 No.2 November 2020 Page.1274-1284

Table 4. Frequency Distribution of Tuberculosis Recurrence Prevention

Efforts in terms of Perceived Seriousness in West Lombok in $2019(n=58)$

\begin{tabular}{llll} 
No & (Perceived Seriuosness) & Frequency & Percentage \\
\hline 1. & Good & 45 & 78 \\
\hline 2. & Enough & 3 & 5 \\
\hline 3. & Less & 10 & 17 \\
\hline Total & & 58 & 100 \\
\hline
\end{tabular}

Source: Primary Data

Perceived Benefits

Perceived Benefits for tuberculosis based on table 5 shows that as many as 47 respondents $(81 \%)$ both did prevention seen from the perceived benefits.

Table 5. Frequency Distribution of Tuberculosis Recurrence Prevention Efforts in terms of the Perceived Benefits of West Lombok in $2019(n=58)$

\begin{tabular}{llll}
\hline No & (Perceived Benefits) & Frequency & Percentage \\
\hline 1. & Good & 47 & 81 \\
\hline 2. & Enough & 6 & 10 \\
\hline 3. & Less & 5 & 9 \\
\hline \multicolumn{2}{c}{ Total } & 58 & 100 \\
\hline
\end{tabular}

Source: Primary Data

Perceived Barriers

Measures to prevent the recurrence of Tuberculosis based on table 6 show that as many as

39 respondents $(67 \%)$ were good at prevention seen from the perceived obstacles

(Perceived Barries)

Table 6. Frequency Distribution of Tuberculosis Recurrence Prevention Efforts in terms of Perceived Barriers, West Lombok, 2019 ( $n=58)$

\begin{tabular}{llll}
\hline No & (Perceived Barrierss) & Frequency & Percentage \\
\hline 1. & Good & 39 & 67 \\
\hline 2. & Enough & 12 & 21 \\
\hline 3. & Less & 7 & 12 \\
\hline Total & & 58 & 100
\end{tabular}

Source: Primary Data

\section{Cues to Action}

Tuberculosis recurrence prevention action based on table 7 shows as many as 38 respondents $(65 \%)$ are good at doing prevention seen from the cues to action.

Table 7. Frequency Distribution of Respondents on Efforts to Prevent Tuberculosis Recurrence in terms of Cues to Action in West Lombok in $2019(n=58)$

\begin{tabular}{llll}
\hline No & I(Cues to Action $)$ & Frequency & Percentage \\
\hline 1. & Good & 38 & 65 \\
\hline 2. & Enough & 11 & 19 \\
\hline 3. & Less & 9 & 15 \\
\hline Total & & 58 & 100 \\
\hline
\end{tabular}

Source: Primary Data 


\section{STRADA Jurnal Ilmiah Kesehatan}

DOI: $10.30994 /$ sjik.v9i2.463

ISSN: 2252-3847 (print); 2614-350X (online)

Vol.9 No.2 November 2020 Page.1274-1284

\section{DISCUSSION}

According to the theory of the Health Belief model, individuals feel a threat to their disease caused by several factors, namely: First, perceived susceptibility is the individual's perception when seeking treatment if a disease becomes a threat to him. Second, perceived seriousness is the individual's perception when they do not take medication if there is a symptom of the disease. The fourth perceived barriers are the individual's assessment of whether the treatment is as expected and whether it is difficult to get it. The last is cues to action, a cue or individual motivation in preventing disease or attempts to take medication (Stretcher and Rosenstock, 1997).

TB disease is a disease related to breathing. The signs and symptoms that often appear include coughing for two weeks or more, fever, weight loss, frequent sweating at night, experiencing chest pain and frequent fatigue (WHO, 2013). Based on the health behavior model, behavior change is influenced by several individual perceptions about their vulnerability and the severity of certain diseases (Tola et al., 2016). HBM theory is a theory that uses a behavior change approach through an interpersonal approach. HBM involves five components of perception, namely perceived susceptibility, perceived seriousness, perceived perceived benefits, perceived barriers and cues to action. action). In addition, internal and external factors as well as individual motivation can influence behavior change.

The risk that each individual has for the health response he experiences depends on several factors such as the Health Belief Model theory, the individual's perception of the threat of disease to himself, how much the individual's perception of danger or the level of severity that threatens him encourages individual behavior to seek treatment. Furthermore, individual perceptions of the benefits that will be obtained if treatment is also a component that encourages changes in treatment seeking behavior. The challenge is about the individual's perception of the treatment that will be obtained whether there are obstacles such as high costs, and the level of difficulty in obtaining it. then the cues to action is an individual cue to take medication or preventive action (Stretcher and Rosenstock, 1997).

The application of the HBM concept in behavior change has been used in previous research, namely in the prevention of dengue hemorrhagic fever (DHF) at Sukorame Public Health Center, Kediri City, there is a relationship between perceptions of vulnerability and the level of severity of dengue prevention behavior with $r$ values of 0.292 and 0.406 , respectively. . In addition, the cue factor to take action had the highest value, namely 0.439 and the $r$ value of 0.239 for the perceived benefit. Meanwhile, the perception of obstacles has a negative correlation but it has no statistical relationship with a value of $r$ $=-0.122$ and a $\mathrm{p}$ value of 0.144(Attamimy and Qomaruddin, 2018).

Providing education to tuberculosis patients at the Simomulyo Health Center in Surabaya shows that there are differences in the average increase in knowledge and perceptions before and after being given education. With the results of the data from the paired $\mathrm{T}$ test showing the number $\mathrm{p}=0.000$ on knowledge, perceived vulnerability $\mathrm{p}=$ 0.000 , perceived seriousness $p=0.000$, perceived benefits and barriers $p=0.000$ and initiative for preventive action $\mathrm{p}=0.000$ (Patricia Nevada Bilqis, Darjati, 2020).

The role of the family in caring for family members who suffer from illness, for example in Tuberculosis patients in Poasia Kendari. Families have a perception of vulnerability in dealing with Tuberculosis, because they are considered to be infectious to other family members. Actions taken in preventing the disease are separating eating and drinking utensils from the sufferer, when interacting with other people the patient uses a mask, and not sleeping side by side with the patient for too long. The perception of 


\section{STRADA Jurnal Ilmiah Kesehatan}

DOI: $10.30994 /$ sjik.v9i2.463

ISSN: 2252-3847 (print); 2614-350X (online)

Vol.9 No.2 November 2020 Page.1274-1284

seriousness is shown by the family immediately taking treatment because tuberculosis is considered a disease that must be treated immediately. There are also families who consider pulmonary TB disease not serious so they don't make the disease a threat, this is also influenced by the knowledge possessed by these family members (Risdayani, Bahar and Nirmala, 2016).

\section{Tuberculosis Recurrence Prevention Based on the Health Belief Model Theory}

The results of the data obtained are in accordance with the HBM theory regarding the respondent's efforts in taking TB disease prevention measures in the good category with a percentage of $72 \%$. This is supported by individual perceptions of health threats regarding the benefits for disease prevention. The effectiveness of knowledge, walking and diet on bone mass with the HBM model shows that in women suffering from osteoporosis in a health center in Fasa City, Fars Province, Iran after being given intervention, a case group demonstrated a significant increase in knowledge, both on perceived vulnerability, perceived severity and benefits as well as perceived barriers, self-efficacy, internal cues to action, nutrition and walking performance compared to the control group (Khani Jeihooni A, Hidarnia A, Kaveh MH, 2015). Likewise, research to determine the effect of health promotion education programs on self-efficacy, health promotion behavior, and quality of life of middle-aged women in Korea. Educational programs have an effect on increasing knowledge and can be used as an effective public health intervention in the community (Soonyoung Park, Hee yeon yeom, 2019). The results of a study with HBM theory with psychological and educational interventions to improve TB treatment adherence in Ethiopia carried out in patients enrolled in health centers resulted in a significant difference with respect to the non-adherence rates between the intervention and control groups after the intervention, the non-adherence rate decreased among the intervention groups from 19.4 (at baseline) to $9.5 \%$ (at end point), while it increased among control groups from 19.4\% (baseline) to 25.4\% (endpoint) (Ayana, Roba and Mabalhin, 2019).

In understanding specific steps for preventive action, HBM theory provides a framework for these actions (Kumboyono, 2011). According to HBM theory, individual behavior in taking disease prevention will be determined by the individual's perception of disease susceptibility, assuming that the disease is serious and believing in the effectiveness of prevention and treatment, and accepting suggestions for taking action.

\section{Prevention of Recurrence of Tuberculosis in terms of Perceived Susceptibility}

As many as $72 \%$ of respondents are in the good category in preventing Tuberculosis recurrence (perceived susceptibility) so that efforts to prevent Tuberculosis from relapse are increasing. The knowledge that family members have about Tuberculosis has an impact on my behavior to protect other family members by wearing masks, separating equipment eating and drinking (Risdayani, Bahar and Nirmala, 2016). Likewise, the opinion of Firda et al, respondents who felt that they were vulnerable to disease $(82.3 \%)$ compared to those who felt vulnerable $(17.7 \%)$ The more vulnerable a person is, the better because the tendency to behave well will also be greater. Respondents felt that they were vulnerable as seen from the number of respondents who agreed that when they had direct contact with TB sufferers they could be infected, felt that TB could be transmitted through coughing and sneezing (Safri, Sukartini and Ulfiana, 2019).

The assessment of vulnerability perceptions carried out by Nevada Bilqis, et al. Showed that patients with pulmonary tuberculosis got results in the category of 35 people $(89.7 \%)$, while the good category was 4 people $(10.3 \%)$. The results of the post-test in assessing the perception of vulnerability showed an increase in the sufficient category of 


\section{STRADA Jurnal Ilmiah Kesehatan}

DOI: $10.30994 /$ sjik.v9i2.463

ISSN: 2252-3847 (print); 2614-350X (online)

Vol.9 No.2 November 2020 Page.1274-1284

14 people $(35.9 \%)$ and the good category by 25 people $(64.1 \%)$. The difference in the increase in the average perception of vulnerability is 0.538 . Because the Sig. (2-tailed) value in the test results got a value of 0,000 which means there is a difference between the pre and post test results. The perception of vulnerability itself is the assumption that a person feels a risk of developing a disease so that he takes preventive action or treatment (Patricia Nevada B, Darjati, 2020).

Literature review research on facemask use was conducted on the websites of Medline, PubMed, Google, the World Health Organization and the Singapore government, using search terms such as facemasks, masks, influenza, respiratory infections, personal protective equipment, disease prevention, and adherence. It is conveyed that individual perceptions in the behavior of taking health actions are strongly influenced by perceived susceptibility which seems to be the most significant factor in determining compliance(Sim, Seng and Moey, 2014) .

Prevention of transmission and seeking treatment for Tuberculosis will be carried out if each individual feels that the disease is at risk of transmitting to others. Respondents in preventing the transmission of tuberculosis based on their perceived vulnerability, some of the actions were to remove phlegm in the bathroom toilet, always drying the mattress and opening the window every morning and knowing how to cough effectively. Most of the respondents know how to cough which is effective, so if they cough they always cover it with a sleeve or a handkerchief. Effective coughing behavior can reduce the transmission of Tuberculosis to others, because respondents feel that by knowing how to cough effectively in the family environment, the family will avoid transmission of Tuberculosis.

\section{Prevention of Recurrence of Tuberculosis in terms of Perceived Seriousness}

As many as $78 \%$ of respondents are in the good category to know the severity of Tuberculosis they suffer so that respondents have the willingness to make efforts to cure the disease and take prevention so that transmission does not occur. Studies on high school students in Shanghai, China through community-based school health education have an impact the largest is the perceived seriousness associated with injuries among high school students after the intervention (Zhi-Juan, Yue and Shu-Mei, 2014). Most respondents are men and young adults feel that healing and reducing transmission of family members are their concerns. Based on the HBM theory the results of a systematic review were carried out to identify study interventions that used HBM as a theoretical basis for intervention design from 18 eligible studies $(78 \%)$ reporting a significant increase in adherence (Jones, Smith and Llewellyn, 2013).

\section{Prevention of Recurrence of TB in terms of Perceived Benefits}

As many as $81 \%$ of respondents are in the good category to know the benefits that are taken when taking preventive measures and treatment of Tuberculosis so that there is no recurrence. The existence of TB program holders in West Lombok has good knowledge and attitudes because they have responsibility for the risk of TB disease if not treated well. So that it will reduce the negative stigma in society by providing information to respondents about the impact of transmission on the family making respondents increasingly aware of the importance of obedience in the treatment program. The ability of officers to increase the knowledge of these respondents is in accordance with the results of research by Naidoo et.al., on health workers in the Manhica district of Mozambique 70\% of respondents agreed that reducing the stigma in society through education to patients and families is important so that the cure and prevention of Tuberculosis will be successful (Naidoo et al., 2020). 


\section{STRADA Jurnal Ilmiah Kesehatan}

DOI: $10.30994 /$ sjik.v9i2.463

ISSN: 2252-3847 (print); 2614-350X (online)

Vol.9 No.2 November 2020 Page.1274-1284

\section{Prevention of TB Recurrence in terms of Perceived Barriers}

As many as $67 \%$ of respondents are in the good category knowing the obstacles to be faced so that they want to take preventive measures so that Tuberculosis does not recur. The HBM theory regarding perceived barriers states that the high obstacles faced will affect the low willingness of individuals to take prevention. The results showed that the obstacles faced will have an impact on actions in maintaining health. The identification of perceptions of perceived benefits and barriers by Firman Maulana Safri, et al. Showed that $83 \%$ of respondents felt the benefits and low barriers during pulmonary TB treatment. Meanwhile, as many as 3\% of respondents felt the benefits and high obstacles in treating Pulmonary Tuberculosis (Safri, Sukartini and Ulfiana, 2019).

Research on perceptions related to the obstacles felt by Istiana, et al in Klaten, Central Java shows that sufferers can overcome obstacles during the treatment process and do not change their trust in health workers. This is evidenced by the TB treatment cards of all participants filled in according to the control schedule and drug taking carried out by BALKESMAS health workers, as well as discipline in taking medications as prescribed (Nurhidayati, Sulistyowati and Dewi, 2019).

\section{Prevention of TB Recurrence in terms of Cues to Action}

As many as $65 \%$ of respondents are in the good category in terms of acting as an effort to prevent and treat Tuberculosis to prevent recurrence. The results of research conducted by Istiana, et al in Klaten, Central Java regarding family support (husband, wife, children, brother-in-law), neighbors, and friends) are very influential on sufferers during treatment, such as giving attention and encouragement to sufferers. This is in accordance with research on medication adherence and supervision of taking medication for support from family and community(Nurhidayati, Sulistyowati and Dewi, 2019).

The importance of information and support from health workers and those closest to them makes it an impetus for doing better activities, as the results of a study by Nevada Bilqis et al showed an increase of 35.9\% after counseling for Tuberculosis patients. Cues to action are a condition where individuals have cues. or motivation to take action in accordance with health behavior guidelines (Redding et al., 2001), for example, accept or reject preventive action. Action cues are internal (coming from the individual himself) and external (coming from outside the individual). Examples of internal cues are individual actions that are taken if they have symptoms of a disease that is felt, while external cues are in the form of closest people, health workers and information from the mass media related to signs in acting in preventing disease. The factors above affect respondents' perceptions of taking TB recurrence prevention measures according to considerations of the susceptibility, severity of Tuberculosis as well as the obstacles and benefits arising from prevention. Education, work and knowledge also affect the health behavior of each individual.

\section{CONCLUSION}

The respondent's efforts to prevent the recurrence of tuberculosis were categorized as good. The need for family participation in preventing recurrence of tuberculosis by respondents such as carrying out routine checks, avoiding allergens, doing regular sports activities. Providing information and counseling about tuberculosis by health workers is expected to be able to encourage patients to take tuberculosis recurrence prevention measures. 


\section{STRADA Jurnal Ilmiah Kesehatan}

DOI: $10.30994 /$ sjik.v9i2.463

ISSN: 2252-3847 (print); 2614-350X (online)

Vol.9 No.2 November 2020 Page.1274-1284

\section{ACKNOWLEDGEMENT}

The author would like to thank the Chair of the Yarsi Mataram Stikes for the cost assistance for this research as well as the Head of Gunungsari Health Center, Tuberculosis program officers and health cadres who have supported the implementation of the research.

\section{REFERENCES}

Attamimy, H. B. and Qomaruddin, M. B. (2018) 'Aplikasi Health Belief Model Pada Perilaku Pencegahan Demam Berdarah Dengue', Jurnal PROMKES, 5(2), p. 245. doi: 10.20473/jpk.v5.i2.2017.245-255.

Ayana, T. M., Roba, K. T. and Mabalhin, M. O. (2019) 'Prevalence of psychological distress and associated factors among adult tuberculosis patients attending public health institutions in Dire Dawa and Harar cities , Eastern'. BMC Public Health, pp. 1-9.

Firda Safira Ali, Setiawan, N. (2020) 'Hubungan Persepsi Dengan Perilaku Pencegahan Penularan Tuberkulosis Paru Di Puskesmas Perak Timur Tahun 2019', GEMA Lingkungan Kesehatan, 18, pp. 63-68.

Jones, C. J., Smith, H. and Llewellyn, C. (2013) 'Evaluating the effectiveness of health belief model interventions in improving adherence: a systematic review', (November 2014), pp. 37-41. doi: 10.1080/17437199.2013.802623.

Kementerian Kesehatan RI (2014) Pedoman Nasional Pengendalian Tuberkulosis.

Khani Jeihooni A, Hidarnia A, Kaveh MH, H. E. (2015) 'The Effect of a Prevention Program Based On Health Belief Model on Osteoporosis', Journal of Research in Health Sciences journal, 15(1), pp. 47-53.

Kumboyono (2011) 'Analisis Faktor Penghambat Motivasi Berhenti Merokok Berdasarkan Health Belief Model Pada Mahasiswa Fakultas Teknik Universitas Brawijaya Malang', Jurnal Keperawatan Soedirman (The Soedirman Journal of Nursing), $6(1)$, pp. 56-61.

Naidoo, S. et al. (2020) 'Changes in Healthcare Workers' Knowledge about Tuberculosis Following a Tuberculosis Training Programme', pp. 1-6.

Newell, J. N. et al. (2006) 'Family-member DOTS and community DOTS for tuberculosis control in Nepal: Cluster-randomised controlled trial', Lancet, 367(9514), pp. 903-909. doi: 10.1016/S0140-6736(06)68380-3.

Nurhidayati, I., Sulistyowati, A. D. and Dewi, A. Y. K. S. (2019) 'Health Belief Penderita Tuberkulosis Paru Relaps Di Balai Kesehatan Masyarakat (Balkesmas) Wilayah Klaten:Studi Fenomenologi', Jurnal Keperawatan dan Kesehatan Masyarakat Cendekia Utama, 8(1), p. 17. doi: 10.31596/jcu.v8i1.302.

Patricia Nevada Bilqis, Darjati, S. (2020) 'Efek Pemberian Edukasi Health Belief Model Pada Penderita Tuberkulosis Paru Terhadap Pengetahuan Dan Persepsi Kepatuhan Pengobatan', 18(1), pp. 58-64.

Puskesmas, G. (2019) Laporan Tahunan PKM Gunungsari. Gerung.

Redding, C. A. et al. (2001) 'Models of health behavior', Recherche en soins infirmiers, 3(64), pp. 59-77.

Risdayani, R., Bahar, H. and Nirmala, F. (2016) 'Analisis Kualitatif Peran Keluarga Dalam Merawat Anggota Keluarga Yang Menderita Penyatuberkulosis Paru Di Wilayah Kerja Puskesmas Poasia Kota Kendari Tahun 2016', Jurnal Ilmiah Mahasiswa Kesehatan Masyarakat Unsyiah, 1(4), p. 185173.

RISKESDAS (2018) 'Hasil Utama Riset Kesehatan Dasar 2018', Kementrian Kesehatan Republik Indonesia, 1(1), pp. 1-200. doi: 1 Desember 2013. 


\section{STRADA Jurnal Ilmiah Kesehatan}

DOI: $10.30994 /$ sjik.v9i2.463

Safri, F. M., Sukartini, T. and Ulfiana, E. (2019) 'Analisis Faktor Yang Berhubungan Dengan Kepatuhan Minum Obat Pasien Tb Paru Berdasarkan Health Belief Model Di Wilayah Kerja Puskesmas Umbulsari, Kabupaten Jember', Indonesian Journal of Community Health Nursing, 2(2), pp. 12-20. doi: 10.20473/IJCHN.V2I2.11904.

Sim, S. W., Seng, K. and Moey, P. (2014) 'The use of facemasks to prevent respiratory infection: a literature review in the context of the Health Belief Model', 55(3), pp. 160-167. doi: 10.11622/smedj.2014037.

Sinaga and Josetta, Y. dan (2009) 'Tahapan Treatment Delay Ditinjau Dari Health Belief Model Pada Masyarakat Pedesaan', p. 511.

Soonyoung Park, Hee yeon yeom, S. r. S. (2019) 'Effects of health promoting education program for Korean middle-aged women', pp. 5-11.

Stretcher, V. and Rosenstock, I. M. (1997) 'The Health Belief Model', Health Behavior and Health Education: Theory, Research and Practice, pp. 31-36. doi: 10.1111/j.1365-2648.2010.05450.x.

Tola, H. H. et al. (2016) 'Psychological and educational intervention to improve tuberculosis treatment adherence in Ethiopia based on health belief model: A cluster randomized control trial', PLoS ONE, 11(5), pp. 1-15. doi: 10.1371/journal.pone.0155147.

Toth, A. et al. (2004) 'Tuberculosis prevention and treatment: occupational health, infection control, public health, general duty staff, visiting, parish nursing or working in a physician's office -- all nursing roles are key in improving tuberculosis control', Canadian Nurse, 100(9), pp. 27-30 4p.

WHO (2013) Systematic screening for active tuberculosis Principles and recommendations. Geneva, Switzerland.

WHO (2018) TB Global Report. Geneva, Switzerland.

WHO (2019) GLOBAL REPORT TBC 2019. PRANCIS.

Yekrang Sis, H. et al. (2014) 'The Effectiveness of Family-Based DOTS versus Professional-Family Mix DOTS in Treating Smears Positive Tuberculosis.', Health promotion perspectives, 4(1), pp. 98-106. doi: 10.5681/hpp.2014.013.

Zhi-Juan, C., Yue, C. and Shu-Mei, W. (2014) 'Health belief model based evaluation of school health education programme for injury prevention among high school students in the community context', BMC Public Health, 14(1), pp. 1-15. doi: 10.1186/1471-2458-14-26. 